\title{
Views on the Imperative of EU-US Relations
}

\author{
Yusuf Avar', Yu Chou Lin ${ }^{2}$ \\ ${ }^{I}$ Instructor at Kilis 7 Arallk University, PhD Student at Marmara University, European Union Politics and \\ International Relations \\ ${ }^{2}$ Master of EU Politics and International Relations, Marmara University, European Union Politics and \\ International Relations \\ yusufavar@kilis.edu.tr,yuchoulintr@gmail.com
}

\section{Abstract}

The EU Member States share various perceptions and preferences on lots of Union's issues, particularly in the areas of foreign and security policies. Some countries, such as France, Belgium, and Luxembourg, focus on the establishment of the European autonomous defence. Others, especially most of the Central and Eastern European countries, as well as the UK, supported the transatlantic burden sharing. The neutral states also concur with the concept of transatlantic burden sharing. However, the transatlantic relations between the $E U$ and the $U S$ are problematic. This study argues that the EU would increase its importance to the role of international politics to effectively implement its goals if the transatlantic relations are stable. The EU requires the military capability and leadership of the US; on the other hand, the US also relies on the EU's peacemaking and peacekeeping capacity. When both blocs closely cooperate with each other as an important partnership to counter international terrorism, regional disputes, climate change, failed states, mass movements of migration, epidemic diseases, and so on, they would respond to these problems and resolve them within a shorter time.
Keywords

European Uhion; Uhited States of America; transatlantic burden sharing

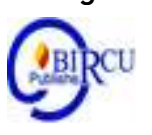

\section{Introduction}

Due to catastrophic war and severe economic depression, European countries reconsidered their best interests in Europe to maintain the post-war peace. In addition, because of the increasingly ideological bipolarization between the USA and USSR, Western Europe not only concerns with economic reconstruction but also was anxious about their fragile defence against the USSR's territorial encroachment. The post-war sentiments are credited with contributing to a new common interest in European unity (Cini, 2009: 26). With external assistance from the USA, the European Coal and Steel Community (ECSC) was established. This infers that the USA plays an essential role of the creation of the ECSC as well as the current European Union (EU). The interests of the EU and the US are closely connected in economics, politics and security; no part of the world has such relations (Riddervold and Newsome, 2018: 505). These two Western powers are the militarily strongest ones and they have the biggest economy in the World. Accordingly, they can be considered as two variants of Western modernity (Martinelli, 2007: 1). They were both Western actors of the bipolar world of the Cold War against the Soviet Union. The USA required the European countries' supports in order to confront the Soviet Union's threats between 1945 and 1990. Currently, they are still two blocs, which depend on each other based on their best common interests and regional stability. 
The decision-making process in the EU is rather problematic. Although the EU is a supranational organization, the EU member states' governments still have a greater say in making policies and political integration, particularly in the field of foreign policy. The perceptions of the EU's foreign policy can be divided into Europeanist and transatlantic burden sharing. First, the Europeanist approach claims the autonomous European defence system so it does not always concur with the North Atlantic Treaty Organization (NATO) and US on security issues to some extent. On the contrary, transatlantic perception has been led by Britain and it refers to NATO primacy and the US presence. The concept of the transatlantic burden sharing is related to the collaboration between EU, NATO, and US for security issues. Foreign, security and defence policies have been mostly at the key subjects of transatlantic relations (Riddervold and Newsome, 2018: 511).

The main purpose of NATO is to create the military alliance between the European countries and American. The EU's defence system heavily depends on the NATO and transatlantic relations. The EU is not able to conduct operations at the desired level. Thus, the EU continually develops its defence capability so as to be an efficient international actor in international arena. For instance, the gradual development of Europe's Common Foreign and Security Policy (CFSP) indicates that the EU determines to be an important actor in international affairs (Chalmers, 2001: 569). The relations between the EU and US are interdependent so that only in close collaboration altogether would both blocs make efficient and effective policies. In terms of the transatlantic relations, the US's priorities are to highlight its hegemony in the world, to enhance its defence capabilities, and to benefit from the EU's market. By contrast, the EU's priorities lie in becoming an influential global actor. Instead of resolving international disputes through military actions, the EU tends to employ the soft power tools, such as the methods of diplomacy or negotiations. Nonetheless, the sheer soft power is insufficient to demonstrate its position in the world politics. In order to successfully achieve its goals for political integration and creating its international presence, the EU's critical demand is to sustain or perhaps propel its transatlantic relations with the US.

This study first aims to briefly explain the concept of transatlantic burden sharing. Second, this concept will be ascertained through the evolution of European security. Third, it applies the transatlantic approach on the matters of cooperation to demonstrate the imperative of building and maintain a stable relation. The main argument of the study is that if the EU desires to be an effective and influential actor in the international politics, it is necessary to acquire its autonomous military capability via preserving stable transatlantic relations.

This study seeks to answer the following questions:

1. What are the natures of transatlantic burden sharing?

2. How do the EU countries have acted towards the stance of Europeanist and transatlantic burden sharing amid the evolution of the European security?

3. Why do the EU and the US require the transatlantic burden sharing for resolving and managing regional and international crisis? 


\section{Review of Literatures}

\section{Concept of Transatlantic Burden Sharing}

Burden sharing debates mainly reflect bargaining over how to share the costs of achieving common objectives (Chalmers, 2001: 569). Namely, "international burden sharing is concerned with the questions how the costs of common initiatives or the provision of international public goods, which should be shared between states" (Thielemann, 2003: 253). The concept of burden sharing mainly is originated from collective action where groups coalesce to fulfill common objective (Forster and Cimbala, 2005: 9). In addition, burden sharing debates can be derived from the notion of equity, that is, the distribution of burdens on some key that is connected to the real capacity of the different participants of the burden sharing. Moreover, burden sharing debates can be perceived under the norm-based perspective, states' commitments to norms that are linked with burden to be shared (Thielemann, 2003: 258). Shared norms and values are crucial for maintaining a collective identity and also practices are adequately important for reproducing these values and promoting their expansion (Adler, 2008: 220). For instance, the EU military operations are conducted in according with logic of justification, the goal and kind of reasons that serve to justify the deployment of a operation (Palm and Cum, 2019: 518).

Chalmers (2001) contends that transnational burden sharing had a mono-dimensional during the Cold War, and dealt primarily with national contributions to NATO's defence against Soviet aggression (p. 570). However, the characteristics of burden sharing debates have been changed and now it is more complex and has a multi-dimensional character after the collapse of Soviet Union (Chalmers, 2001: 571). Effective burden sharing has to be identified with clearer defence planning guidelines, capability sharing, and common/joint funding of multinational projects (Kunertova, 2017: 555). Burden sharing between the EU and the US has been the main challenge of political debates (Kivimäki, 2019: 2).

Burden sharing refers to mainly military terms for the US, while it has a multidimensional character for the EU (Chalmers, 2001: 583). The debate of burden sharing is about more than NATO, because humanitarian aid, diplomatic mediation and climate change also can be considered as subjects of the collective security (Foucault and Mérand, 2012: 424). According to European powers, burden sharing debates have been the main challenge in collective security issues since the beginning of the Cold War, because they involved in overlapping crisis management institutions, such as NATO, the UN, and the EU (Mérand and Rayroux, 2016: 444).

\section{Discussion}

\subsection{Evolution of Transatlantic Burden Sharing in View of Historical Development of the European Defence and Security}

European integration process is instigated by a series of severe wars and crisis. Internally, European countries disputed the regions of Saar and Ruhr. After World War II, European countries anticipated to make war between France and Germany not merely unthinkable, but materially impossible (Schuman Declaration,1950). Externally, European countries feared the aggression by the USSR in the late 1940s (Cini, 2009: 17). In this regard, European countries were so urgent that they must define their common interests and take measures to safeguard their security. Today, security management transferred to the EU level, but they are still controlled by member states to some extent (Giumelli and Lavallée, 2013: 366). 
NATO was established within the lead of USA in 1949. NATO is the guarantee of European security (Kurečıč, 2008: 219). The USA helped the European countries in order to ward off the Soviet Union's power in the region. Additionally, the US attempted to create an army in Europe. Because Churchill signed out the permission of European army to protect themselves, the involvement of the US heavily impacted on the inception of European security. In the process of developing the alleged European security, the question as to Germany's rearmament against Soviet threats was controversial. Germany's priority was to create ECSC at first. In addition to the ECSC, the EPC and the EDC are concerned with the foreign policies and European defence and security. As for the EPC, economic integration would follow political integration/NATO approval. For the EDC, Pleven plan suggested to implement a supranational defence project. The US endorsed the plan because commander would be European but not American. Lisbon Summit by NATO held positive opinion about the establishment of the European army. However, French National Assembly rejected the EDC. In 1954, nine powers conference took place and attempted to seek a consensus of organization and defence in Western Europe. Subsequently, modified Brussels Treaty transformed the Western Union into the Western European Union and admitted West Germany.

In accordance to Article IV of North Atlantic Treaty, it urges member states utilize the mechanism of consultation over military matters when "the territorial integrity, political independence, or security of any of the parties is threatened." The process of consultation between member states shapes the common interest among them. In addition, it also enables allies to exchange views and information as well as discuss issues prior to reaching agreement and taking action. Moreover, this process typically represents the importance of the transatlantic approach. Furthermore, becoming a member of the European Economic Community (EEC) nearly means identical to the membership of the NATO. Germany became a member of NATO in 1955. After 5 days of Germany's NATO membership, Warsaw Pact was established in May 1955. Oil Crisis in 1973 shocked the world politics. This led the member states to re-consider their interests in the Gulf States and to forecast the possible implications for NATO.

On the other hand, Kissinger questioned whether European countries could speak one voice. Venice Declaration of 1980 recognized Palestinians sufferings and right to selfdetermination and also it conferred right to Israel to exist as a Jewish state within the borders of 1966. Based on the EU Treaty, the structure of WEU was debatable. Accordingly, the Common Foreign and Security Policy (CFSP) aims to generate the autonomous defence capacity. The creation of genuine European Security and Defence identity results in the Transatlantic sharing burden. In 1991 Rome Summit, NATO Strategic Concept underlines some balanced burden sharing identity. In addition, NATO came up with three initiatives: (1) combined joint task forces, (2) European Security and Defence Identity, and (3) the partnership for peace.

In 1998 Saint Malo Summit, France and Britain suggested that the EU should have the autonomous capability for security and defence issues. Next year, NATO Washington Summit welcomed the EU's autonomous defence capability. In the following years, there are three crucial European Council meetings in Cologne (1999), Helsinki (1999), and Sintra (2000). These meetings aims to make the European Security and Defence Policy more than just an EU paper policy (Cini, 2009: 248). In the Cologne meeting, member states expected to reach their goals having the autonomous defence capability at the end of 2000. Second, the Helsinki Summit was crucial for setting framework for European Security and Defence Policy. It has certain capability goals such as Command, Strategic Planning, Control Mechanism between the EU and NATO. Accordingly, European 
countries, as for the European defence, would have recourse to NATO to safeguard their security. The Washington Summit declared that European counties should prevent the 3D (decoupling, duplication, and discrimination) against the transatlantic relations. Poland, Hungary and Czech Republic joined the NATO in 1999. The primary aim of the Berlin+ Agreements is that the NATO capability would be available for the EU. That is, the EU would have opportunity to access non-strategic assets directly despite the EU needs to ask for permission to utilize the assets.

The division between transatlanticist and Europeanist could be traced back to the Iraq crisis. Some countries, such as the UK, Spain, Portugal, Italy, Denmark, the Netherlands, and the new members of central and eastern European endorsed the USA's contention; conversely, others, for instance, Germany, France, Belgium, and Luxembourg were against the US's positions (Kurečič, 2008: 223). The transatlanticsts criticized the Europeanist countries that they failed to meet the commitment to the collective defence. (Espen, 2005). Belgium, France, Germany, and Luxembourg supported that the EU should create its headquarter, interwoven, duplication strategic assets while Netherlands supports the USA. Denmark (opt-out from the ESDP) and the UK support the transatlantic cooperation. Through the application of Berlin+ arrangements: The EU would apply NATO assets capability for operations. The EU can act in NATO operations, for example, framework nations/led nation headquarters and use of civil military in the EU from Brussels. Helsinki Summit in 2004 decided several policies, such as the creation of European Defence Agency (taken from WEU, originally NATO group) and the creation of the Battles Groups Initiatives.

The EU prepared its first security strategy in 2003. The 2003 European Security Strategy focuses on the comprehensive approach to security (internal security and external security), civilian and military (Giumelli and Lavallée, 2013: 366). It argues, "for Europe, the transatlantic partnership remains an irreplaceable foundation, based on shared history and responsibilities." The EU and NATO must deepen their strategic partnership for better co-operation in crisis management" (European Security Strategy, 2003: 9). It continued as such:

The transatlantic relationship is irreplaceable. Acting together, the European Union and the United States can be a formidable force for good in the world. Our aim should be an effective and balanced partnership with the USA. This is an additional reason for the EU to build up further its capabilities and increase its coherence (European Security Strategy, 2003: 42).

According to Cimbala and Forster (2017: 119), "without American leadership, the international system would have been decidedly more anarchic. Other rogue states would have sought increased power while generally heightening the perceived sense of insecurity." Forster and Cimbala (2005: 166), further claim that for the international order American leadership and its commitments continue to remain a prerequisite. In order to point good relations with the US, Global Strategy for the EU's Foreign and Security Policy (2016: 20) states that:

The EU needs to be strengthened as a security community: European security and defence efforts should enable the EU to act autonomously while also contributing to and undertaking actions in cooperation with NATO. A more credible European defence is essential also for the sake of a healthy transatlantic partnership with the United States. 


\subsection{Transatlantic Burden Sharing Analysis on the EU-US Relations}

The EU and the USA are the richest and militarily and politically strongest blocs of the word politics. The transatlantic relations are influenced by American unilateralism and European multilateralism. (Kurečič, 2008: 219). The US has the largest and modernized economy in the world; however the US is not the centre for the Roman Catholic Church, transnational political parties and revolutionary movements (Nye and Keohane, 1971: 347). The EU requires the USA to share the common values and protect the collective interests, as a whole while the US needs the EU to deploy peace-making and peacekeeping operations. Due to the togetherness, they have sufficient capabilities to tackle many international disputes and crisis (Kurečıč, 2008: 230). The EU mostly deals with the world economic crisis, climate change and its aftermath, the poverty, and other social problems. In contrast, the US is more into resolving rouge states and the weapons' dissemination of mass destruction (Kurečič, 2008: 221).

The fields of the European security arguably comprise three main elements: EU member states (Germany, France, and the UK), Brussels (NATO and the EU), and New York (the UN) (Mérand And Rayroux, 447). In general, Denmark does not support the EUled operations; on the contrary, it is active in NATO/US-led operations. In addition, the UK and Baltic states are also contributed to the NATO/US-led operations. France predominantly focuses on EU-led missions (Dorussen, Kirchner and Sperling, 2009: 801802). France, Spain, Belgium, and Luxembourg attempt to develop ESDP as an alternative to NATO (Hofmann, 2009: 2016: 47). ESDP and NATO have operational credibility. ESDP has conducted many operations and missions since 2001 (Hofmann, 2009: 45).

During the period of Clinton between 1993 and 2001, the transatlantic relations between the EU and US were stable based on the mutual respect and equality. However, their relations deteriorated since the period of G. W. Bush (Kurečıč, 2008: 220). After the terror attacks of 9-11, international terrorism, and failed states, the EU and other international organizations increasingly pay attention on these novel security threats so that their policy-making became various (Cimbala and Forster, 2017: 115).

The EU conducted its first military operation in 2003: Operation Concordia in the FYR Macedonia (Palm and Crum, 2019: 513), and also the EU launched Artemis military operation in Congo, and in 2004 the EU launched Operation Althea in BosniaHerzegovina, taking over from a preceding NATO operation (Palm and Crum, 2019: 522). All of these operations have value-based terms: implementing peace-agreements and protecting civilians (Palm and Crum, 2019: 524). In Bosnia, the UN's intervention failed and it led to the continuous hostility. Additionally, in Kosovo, delayed NATO intervention resulted in ethnic cleansing (Forster and Cimbala, 2005: 153). If the US did not apply successfully military and diplomatic pressure, the wars would not have ceased (Cimbala and Forster, 2017: 119). The demands of the US military supports could be observed in the case of Bosnia and Herzegovina under Berlin Plus arrangements (Espen, 2005).

Russia was in war against Georgia in 2008 in order not to permit the NATO expand its membership. Russia confronted with the EU and the USA when they annexed Crimea and attempted to acquire the territory of Ukraine. A paradigm state in outer Europe believes that Atlantic cohesion is so vital that the relations create the balance of interests. In contrast, a paradigm state in inner Europe focuses on the deepening integration and the development of the independent ESDP (Mouritzen, 2010: 5-6). Events in Georgia and Ukraine demonstrate that the interests of two blocs are so interdependent that they must settle disputes and handle the threats altogether. Thus, these cases indicates that they cannot arbitrarily withdraw the cooperation. 
Regional disputes, Brexit, and the foreign policies made by Trump administration were negatively affected the relations between the EU and the US. Trump challenged some core points of transatlantic relations, such as the US defence guarantee, international trade disputes, withdrawing the Paris Accord on climate change, and questioning the function of the international organizations (Riddervold and Newsome, 2018: 505). The transatlantic relations are under the great detriment because of the Brexit since the UK is the gatekeeper and guarantees of the alliance with the US. (Martinelli, 2007: 248). Along with the Brexit, one of the most influential members of the Union and which has Atlanticist vision left (Cebeci, 2018: 174), and it may greatly affect on transatlantic relations.

\section{Conclusion}

The disputed argument of ascertaining the nature of the creation of the EU whether based on the concept of transatlantic burden sharing or Europeanist perception or not. Importantly, the security of the EU heavily depends on the geopolitics. The transatlantic burden sharing approach is rather beneficial for the EU to create and further develop its autonomous security. Therefore, in order to show its actorness of the EU and implement effective foreign policies with other international actors, the EU cooperation with the US/NATO is the prerequisite to the goal.

Despite the fact that such relations may be endangered by international affairs, such as Iraq War, different administration of the US (Bush or Trump), and Brexit, both blocs still should act together for the common interests and values. The EU and the USA/NATO require the stable cooperation and intelligence sharing via various means of policy-making tools, no matter military or civilian measures or not. They are still bound to democratic values and deep common interests (Moisi, 2001). The US must pursue the global strategy, which contains multilateralism, liberal internationalism, and the universal values. On the other hand, the EU should enhance its ability to immediate respond to the crisis, make and take decisions instantly in the security policy. (Hallenberg and Karlsson, 2006: 215).

In conclusion, the relations of the transatlantic burden sharing gain in importance via the evolution of the European security. However, the EU still lacks the political actorness to speak with one voice on various international issues. European countries must maintain their relations with their Atlantic alliance to secure their common values and interests as a whole. Simultaneously, the USA also should shoulder more responsibilities for sustaining the relations with the EU because of the application of soft power. Both regional blocs are able to effectively strike for the peace, prosperity, and regional stability (Forster and Cimbala, 2005: 153). In addition, they should counter the international terrorism, mass destruction, climate change, and so on. Moreover, issues, related to the curb on Iran's nuclear ambitions, the plans of lifting the arms embargo on China, and the provision to assist African continent, rely on multifaceted approaches (Bozo, 2015: 3). The researchers may study these specific subjects, which may bring the great implication to the transatlantic relations. All in all, the 2003 EU's security strategy and its 2016 global strategy reaffirm that a stable relations with the USA/NATO are sine qua non for its actorness and existence. 


\section{References}

Adler, E. (2008). The spread of security communities: communities of practice, selfrestraint, and NATO's Post-Cold War Transformation. European journal of international relations, 14 (2), 195-230.

Cebeci, M. AB'nin Güvenlik ve Savunma Politikalarında Güncel Tartışmalar. Hukuki, Siyasi Ve İktisadi Yönleriyle Avrupa

Bütünleşmesinde Son Gelişmeler Ve Türkiye-Ab İlişskileri Ataum 30. Yıl Armağanı, 151.

Chalmers, M. (2001). The Atlantic burden-sharing debate-widening or fragmenting?. International Affairs, 77 (3), 569-585.

Cimbala, S. J., \& Forster, P. (2005). The US, NATO and military burden-sharing. Routledge.

Cimbala, S. J., \& Kent Forster, P. (2017). The US NATO and military burden sharing: post-Cold War accomplishments and future prospects. Defense \& security analysis, 33 (2), 115-130.

Cini, M., \& Borragán, N. P. S. (Eds.). (2016). European union politics. Oxford University Press.

Dorussen, H., Kirchner, E. J., \& Sperling, J. (2009). Sharing the burden of collective security in the European Union. International organization, 63 (4), 789-810.

Eide, E., \& Bozo, F. (2005). Debate: Should NATO Play a More Political Role?. NATO Review.

Foucault, M., \& Mérand, F. (2012). The challenge of burden-sharing. International Journal, 67(2), 423-429.

Giumelli, F. and Lavallée, C. (2013). 'EU Security Governance: From Processes to Policies', Journal of Contemporary European Research. 9 (3), 365-371.

Hallenberg, J., \& Karlsson, H. (2006). Changing Transatlantic Security Relations. Taylor $\&$ Francis.

Hartley, K., \& Sandler, T. (1999). NATO burden-sharing: past and future. Journal of peace research, 36(6), 665-680.

Hofmann, S. C. (2009). Overlapping institutions in the realm of international security: The case of NATO and ESDP. Perspectives on politics, 45-52.

Kivimäki, T. (2019). Power, contribution and dependence in NATO burden sharing. European Security, 28(1), 66-84.

Kunertova, D. (2017). One measure cannot trump it all: lessons from NATO's early burden-sharing debates. European security, 26(4), 552-574.

Kurečić, P. (2009). Bridging the Transatlantic Divide: The American-European Relations and their Influence on European Unification. Društvena istraživanja-Časopis za opća društvena pitanja, 18(99+ 100), 219-241.

Martinelli, A. (Ed.). (2007). Transatlantic divide: comparing American and European society. Oxford University Press.

Mérand, F., \& Rayroux, A. (2016). The practice of burden sharing in European crisis management operations. European security, 25(4), 442-460.

Moisi, D. (2001). The real crisis over the Atlantic. Foreign Affairs, 149-153.

Mouritzen, H. (2010). 'Old'versus' new'Europe: The 2002-08 straitjacket of European geopolitics (No. 2010: 10). DIIS Working Paper.

Nelson, D. N. (2002). Transatlantic transmutations. Washington Quarterly, 25(4), 51-66.

Nye, J. S., \& Keohane, R. O. (1971). Transnational relations and world politics: An introduction. International organization, 25(3), 329-349. 
Oneal, J. R. (1990). The theory of collective action and burden sharing in NATO. International organization, 379-402.

Palm, T., \& Crum, B. (2019). Military operations and the EU's identity as an international security actor. European security, 28(4), 513-534.

Riddervold, M., and A. Newsome. 2018. "Transatlantic Relations in Times of Uncertainty: Crises and EU-US Relations." Journal of European Integration 40 (5): 505-521.

Schuman, R. (1950). The Schuman Declaration. http://eubg.eu/upload/files/662783579_Shumann.pdf (accessed 05.11.2020).

Solana, J. (2004). A Secure Europe in a Better World. European Security Strategy. Civilian perspective or security strategy? European development policy confronting new challenges in foreign and security policy.

Stahl, B., Boekle, H., Nadoll, J., \& Jóhannesdóttir, A. (2004). Understanding the Atlanticist-Europeanist divide in the CFSP: comparing

Denmark, France, Germany and the Netherlands. Eur. Foreign Aff. Rev., 9, 417.

Thielemann, E. R. (2003). Between interests and norms: Explaining burden-sharing in the European Union. Journal of refugee studies, 16(3), 253-273.

Vaisse, J. (2003). From Transatlanticism to Post-Atlanticism. the National Interest, 2(27), 14-18.

Vision, S. (2016). Common Action: A Stronger Europe. A Global Strategy for the European Union's Foreign and Security Policy, 47.

Wyatt-Walter, H. (2016). The European community and the security dilemma, 1979-92. Springer.. 